\title{
Regulation of growth and some key physiological processes in salt-stressed maize (Zea mays L.) plants by exogenous application of asparagine and glycerol
}

\author{
Cengiz Kaya $^{1 *}$, Salih Aydemir ${ }^{1}$, Osman Sonmez $^{1}$, Muhammed AshraF $^{2}$, \\ Murat DikILITAS ${ }^{3}$ \\ ${ }^{1}$ Harran University, Agriculture Faculty, Soil Science and Plant Nutrition Department, \\ Sanliurfa, Turkey \\ ${ }^{2}$ University of Agriculture, Department of Botany, Faisalabad, Pakistan \\ ${ }^{3}$ Harran University, Agriculture Faculty, Plant Protection Department, Sanliurfa, Turkey
}

\begin{abstract}
Maize seedlings were subjected to concentrations of 0 and $100 \mathrm{mM}$ of $\mathrm{NaCl}$ in Hoagland's nutrient solution medium in plastic pots containing perlite. Two levels of asparagine $(5$ and $10 \mathrm{mM})$ and glycerol $(20$ and $40 \mathrm{mM})$ were sprayed onto the leaves of maize seedlings 10 days after germination. Saline stress caused considerable decline in total dry mass, chlorophyll content and relative water content in the maize plants. It increased the activities of superoxide dismutase, catalase and polyphenol oxidase as well as electrolyte leakage, but did not alter the activity of non-specific peroxidise. Foliar application of asparagine or glycerol was found to be effective in checking shoot growth inhibition under $\mathrm{NaCl}$ stress. Exogenously applied asparagine or glycerol reduced superoxide dismutase, non-specific peroxidase and polyphenol oxidase activities in salt-stressed maize plants compared to those not treated with these organic compounds. Salinity increased $\mathrm{Na}^{+}$contents but reduced those of $\mathrm{K}^{+}, \mathrm{Ca}^{2+}$ and $\mathrm{P}$ in the roots of the used genotype of maize. Foliar application of asparagine or glycerol increased the contents of $\mathrm{K}^{+}, \mathrm{Ca}^{2+}$ and $\mathrm{P}$, but it reduced that of $\mathrm{Na}^{+}$in salt-stressed maize plants as compared to those of the salt-stressed plants not supplied with glycerol or asparagine. Glycerol was more effective than asparagine in improving salinity tolerance of maize plants in terms of growth and physiological attributes measured in the present study.
\end{abstract}

Keywords: asparagine, corn, glycerol, maize, salinity tolerance

Abbreviations: Asn - asparagine, CAT - catalase, G - glycerol, PPO - polyphenol oxidase, RWC - relative water content, SOD - superoxide dismutase

* Corresponding author, e-mail: c_kaya70@yahoo.com

Copyright $^{\circledR} 2013$ by Acta Botanica Croatica, the Faculty of Science, University of Zagreb. All rights reserved. 


\section{Introduction}

Soil salinity limits agricultural productivity, particularly in arid and semi-arid regions of the world (YAMAGUCHI and Blumdwald 2005, AshraF et al. 2008; AshraF 2009). Excessive amounts of soluble salts in soil decrease the osmotic potential of the soil solution which impairs uptake of water and nutrients thereby causing ion imbalance and toxicity in plants, while disturbing a variety of other key physiological and biochemical phenomena (LÄUCHLI and GRATTAN 2007). The tolerance mechanisms plants employ to offset the adverse effects of saline stress have been extensively studied in the past (GREENWAY and MunNS 1980, Cushman et al. 1990). One of the key plant responses to salinity stress is the synthesis and accumulation of compatible organic osmolytes including quaternary ammonium compounds (STOREY and Wyn Jones 1977, AshraF and Foolad 2007), amino acids the most promising of which are proline (JAGER and MEYER 1977, FougÈRE et al. 1991, THOMAS et al. 1992), polyols such as sorbitol and mannitol (CHEESEMAN 1988, STOOP et al. 1996), and organic acids (ALBERT and Popp 1977), etc.. All these organic osmolytes are known to play a vital role in osmotic adjustment, a phenomenon which enables a plant cell to maintain turgor.

In plants, asparagine, one of the most common amides, has been reported to be the primary source of $\mathrm{N}$ for protein synthesis, particularly in actively growing tissues (BROUQUISSE et al. 1992). It is synthesized from aspartate and glutamine by the action of asparagine synthase in germinating seeds, where $\mathrm{N}$ released as a result of protein disintegration is transferred to aspartate, or in roots where different forms of $\mathrm{N}$ such as nitrates or dinitrogen are utilized (SIECIECHOWICZ et al. 1988). Some reports show that the synthesis of most of the amides including asparagine, is up-regulated by some environmental cues (RABE 1990, CHAFFEI et al. 2004). Asparagine accumulation in plants in response to environmental adversaries could be an ammonium detoxification mechanism and a means to stock up $\mathrm{N}$ when protein synthesis is impaired in plants due to stressful environments (HERRERA-RODRIGUEZ et al. 2007).

One of the most striking biochemical events taking place in plants exposed to adverse environmental factors is the generation of reactive oxygen species (DIONISIO-SESE and TOBITA 1998, ASHRAF 2009). These reactive oxygen species are known to perturb normal metabolism by causing considerable damage to nucleic acids, lipids, proteins (DAVIES 1987). However, plants possess a variety of antioxidant enzymes which can easily counteract ROS. Of these antioxidative enzymes, superoxide dismutase (SOD) is known to scavenge $\mathrm{O}_{2}{ }^{-}$ thereby producing $\mathrm{H}_{2} \mathrm{O}_{2}$ and $\mathrm{O}_{2}$. The hydrogen peroxide $\left(\mathrm{H}_{2} \mathrm{O}_{2}\right)$ so produced can be scavenged by various peroxidases (POD) (DiONISIO-SESE and TOBITA 1998). Polyphenol oxidase (PPO) is usually used as a molecular marker for ensuring the adequacy of high temperature treatment of fruit purees (WILLIAMS et al. 1986). However, it also acts as a potential selection criterion for salt tolerance For example, while appraising the effect of salinity on senna (Agarwal and Pandey 2004) and bean seedlings (Demir and Kocaliskan 2001) PPO was found to be a good indicator of salinity tolerance in these plants.

Very few reports can be found in the literature on the effect of exogenous application of glycerol or asparagine on growth of plants under salt stress. For example, in Ricinus communis presoaking seed treatment with glycerol or aspartic acid, one of the precursors of asparagine synthesis, improved growth and secondary products (Ali et al. 2008), and in rice seedlings, exogenous application of D-asparagine offset the inhibitory effects of salinity on shoot growth, whereas L-asparagine improved root growth (LIN and KAO 1995). These 
studies suggested a reason to examine the effects of these two organic substances on other crops so as to reinforce the database on the regulatory effects of these compounds on different potential crops. So, the present investigation was undertaken to assess whether exogenous application of asparagine or glycerol to maize plants could improve growth and mineral nutrition. Also assessed was whether exogenously applied asparagine or glycerol could alter the activities of some key enzymes of oxidative defence system involved in counteracting the reactive oxygen species produced in maize plants under salt stress.

\section{Materials and methods}

\section{Plant material and treatments}

Before the initiation of the experiment, the caryopses of maize cv. DK 847 F1 were surface-sterilized in $0.1 \%$ (w/v) sodium dodecyl sulfate solution for 20 min and then thoroughly rinsed with sterile deionized water. The caryopses were then placed on sterile filter paper (two sheets) moistened with deionised water after they had been pre-soaked in deionised water for $6 \mathrm{~h}$ at $28^{\circ} \mathrm{C}$. Five sterilized caryopses were planted in $8 \mathrm{~kg}$ peat contained in each plastic pot and all pots placed in a growth room at $27 \pm 2{ }^{\circ} \mathrm{C}$ with light intensity $350 \mu \mathrm{mol}$ photons $\mathrm{m}^{-2} \mathrm{~s}^{-1}$ and RH ranging from 60 to $70 \%$. Soon after germination, the seedlings were thinned to three per pot. After 7-day growth, treatments of salt and growth regulators were initiated. The salt treatments consisted of control (without $\mathrm{NaCl}$ ) and 100 $\mathrm{mM}$ of $\mathrm{NaCl}$ in full strength Hoagland's nutrient solution. Two levels (5 and $10 \mathrm{mM}$ ) of asparagine (Asn) and two (20 and $40 \mathrm{mM}$ ) of glycerol (G) were sprayed onto the leaves of maize seedlings 10 days after germination. The Asn or $\mathrm{G}$ solutions mixed with $0.01 \%$ of a surfactant solution (Tween-20) were sprayed once a week from day 10 after germination up to day 35 , on the leaves of maize plants at a rate of $50 \mathrm{~mL}$ per pot. The control plants received an equal amount of water containing only $0.01 \%$ Tween-20. The samples were harvested at 35 DAP (days after planting).

The composition of Hoagland's nutrient solution used was ( $\left.\mathrm{mg} \mathrm{L}^{-1}\right)$ : $270 \mathrm{~N}, 31 \mathrm{P}, 234 \mathrm{~K}$, $200 \mathrm{Ca}, 64 \mathrm{~S}, 48 \mathrm{Mg}, 2.8 \mathrm{Fe}, 0.5 \mathrm{Mn}, 0.5 \mathrm{~B}, 0.02 \mathrm{Cu}, 0.05 \mathrm{Zn}$ and $0.01 \mathrm{Mo}$. The $\mathrm{pH}$ of the treatment solutions was maintained at 6.5 by the addition of a few drops of $0.1 \mathrm{mM} \mathrm{KOH}$. Each treatment had four replicates (each containing 3 plants) arranged in a completely randomised design.

\section{Leaf relative water content $(\mathrm{RWC})$}

A fully expanded youngest leaf ( $3^{\text {rd }}$ leaf) from each plant was excised and used to measure RWC following the method described by BARRS and WEATHERLEY (1962). Entire fully expanded leaves were used so as to minimize solute leakage due to excision effect.

\section{Chlorophyll determination}

One plant per replicate was used for measuring chlorophyll content. Fresh leaf samples $(1.0 \mathrm{~g}$ each) were triturated in $90 \%$ acetone. The optical density of each filtered sample was read at 645 and 663 with a Pye Unicam UV-visible spectrophotometer (Model SP6-550, Pye Unican, UK) and chlorophyll concentrations worked out following STRAIN and SVEC (1966). 


\section{Free proline determination}

The protocol devised by BATES et al. (1973) was used to determine free proline in fresh leaves ( $3^{\text {rd }}$ leaf from top). Proportions of fresh leaf samples $(0.5 \mathrm{~g}$ each) were triturated each in $10 \mathrm{~cm}^{3}$ of aqueous sulfosalicylic acid solution (3\%). An aliquot $\left(2 \mathrm{~cm}^{3}\right)$ of the filtrate was treated with $2 \mathrm{~cm}^{3}$ acid-ninhydrin and $2 \mathrm{~cm}^{3}$ of glacial acetic acid. Afterthe mixture was heated for $1 \mathrm{~h}$ at $100{ }^{\circ} \mathrm{C}$ in a water bath, it was extracted with $4 \mathrm{~cm}^{3}$ toluene. The chromophore containing toluene was aspirated, cooled down to room temperature, and the optical density was read at $520 \mathrm{~nm}$.

\section{Electrolyte leakage}

The electrolyte leakage (EL) was estimated following DiONISIO-SESE and TOBITA(1998). Fresh leaf samples ( $3^{\text {rd }}$ leaf) were cut into small pieces $\left(5 \mathrm{~mm}\right.$ length) and placed in $10 \mathrm{~cm}^{3}$ distilled deionized water contained in a test tube. The tubes were heated to $32{ }^{\circ} \mathrm{C}$ in a water bath. After $2 \mathrm{~h}$ of incubation, the initial electrical conductivity of the medium $\left(\mathrm{EC}_{1}\right)$ was measured using a digital conductivity meter (S47-K, Mettler Toledo). Thereafter, all samples were autoclaved at $121{ }^{\circ} \mathrm{C}$ for $20 \mathrm{~min}$ to kill the tissues so as to release all the electrolytes. The samples were then cooled to $25^{\circ} \mathrm{C}$ to record final electrical conductivity $\left(\mathrm{EC}_{2}\right)$. EL was calculated using the following formula:

$$
\mathrm{EL}=\left(\mathrm{E} C_{1} / \mathrm{E} C_{2}\right) X 100
$$

\section{Soluble protein content}

Soluble protein content in the enzyme extracts was determined following BRADFORD (1976) using Bovine Serum Albumin fraction V as a standard.

\section{Enzyme determination}

Fresh leaves ( $0.5 \mathrm{~g}$ each sample) were triturated in $50 \mathrm{mM}$ sodium phosphate buffer $(\mathrm{pH}$ 7.0) containing $1 \%$ soluble polyvinylpyrolidine (PVP). The extract was centrifuged at $20,000 \mathrm{~g}$ for $15 \mathrm{~min}$ at $4{ }^{\circ} \mathrm{C}$ and the supernatant used for the assays of the activities of superoxide dismutase (SOD; EC 1.15.1.1), polyphenol oxidase (PPO; EC 1.10.3.1), catalase (CAT; EC 1.11.1.6) and non-specific peroxidase (POD; EC 1.11.1.7).

The activity of SOD was assayed following the assay described by BEAUCHAMP and FRIDOVICH (1971) for appraising the activity of SOD, which entails monitoring the enzyme's ability to hinder the photochemical reduction of nitro-blue tetrazolium (NBT). One unit of SOD was defined as the amount of enzyme used to inhibit the reduction of cytochrome $\mathrm{C}$ by $50 \%$.

Catalase activity was appraised following KRAUS and AUSTIN-FLETCHER (1994) by assessing the utilization of $\mathrm{H}_{2} \mathrm{O}_{2}$ at $405 \mathrm{~nm}$.

The POD activity was determined following CHANCE and MAEHLY (1955) by adding the tissue extract $(100 \mu \mathrm{L})$ to $3 \mathrm{~mL}$ of assay solution. The enzyme assay solution consisted of 3 $\mathrm{mL}$ of the reaction mixture containing $13 \mathrm{mM}$ guaiacol, $5 \mathrm{mM} \mathrm{H}_{2} \mathrm{O}_{2}$ and $50 \mathrm{mM}$ sodium-phosphate buffer ( $\mathrm{pH}$ 6.5). An increase in absorbance at $470 \mathrm{~nm}$ for 1 min at $25^{\circ} \mathrm{C}$ 
was read on a UV-visible spectrophotometer. The increase in $\mathrm{A}_{470}$ was measured for 3 min and activity expressed as $\Delta \mathrm{A}_{470}$ per $\mathrm{mg}$ of protein per minute

Polyphenol oxidase (PPO) activity was appraised following ZAUBERMANN et al. (1991). Fresh leaf samples $\left(0.5 \mathrm{~g}\right.$ each) were triturated in $10 \mathrm{~mL}$ of $0.1 \mathrm{~mol} \mathrm{~L}^{-1}$ sodium phosphate buffer ( $\mathrm{pH}$ 6.8) and $0.2 \mathrm{~g}$ of polyvinylpyrrolidone (PVP). The samples were centrifuged at $19,000 \mathrm{~g}$ for $20 \mathrm{~min}$, and the supernatant was used for enzyme assay. The increase in absorbance at $410 \mathrm{~nm}$ at $25^{\circ} \mathrm{C}$ was read automatically for $5 \mathrm{~min}$. One unit of enzyme activity was defined as an increase of 0.01 in absorbance per min per mg protein.

\section{Analysis of nutrients and measurement of dry weight}

All shoot and root samples were dried at $65^{\circ} \mathrm{C}$ in an oven to constant dry weights. For chemical analyses, the dried and ground samples were ashed in a muffle furnace at $550{ }^{\circ} \mathrm{C}$ for $6 \mathrm{~h}$, and the white ash so obtained was dissolved in $5 \mathrm{~mL}$ of $2 \mathrm{M}$ hot $\mathrm{HCl}$. After all samples had been properly filtered, the volume of each sample was raised to $50 \mathrm{~mL}$ by adding distilled deionized water. Phosphorus in these sample digests was determined by the vanado-molybdate method. The concentrations of $\mathrm{Na}^{+}, \mathrm{Ca}^{2+}$ and $\mathrm{K}^{+}$in these digested samples were analyzed using inductively coupled plasma (ICP) spectometry (CHAPMAN and PRATT 1982).

\section{Statistical analysis of data}

The experiment was conducted twice under the same environmental conditions. Statistical analysis of the data for two different experiments showed that there were no significant differences between the two experiments. Hence, the data presented here are the means of the two individual experiments. Each experiment was arranged in a completely randomized design and each treatment had four replicates (each containing 3 plants). Data for each attribute were subjected to a one-way analysis of variance and the LSD worked out at $\mathrm{p} \leq 0.05$ using the Statview software programme to compare the treatment means.

\section{Results}

Salinity stress caused a marked suppression in shoot and root dry mass of the maize plants. However, Asn or $\mathrm{G}$ foliar-applied to salinized maize plants proved to be effective in significantly increasing plant dry biomass (Tab. 1). Glycerol was more effective than asparagine in increasing dry mass in salt-stressed maize plants. Root:shoot dry weight ratio increased markedly under salt stress reflecting the fact that shoot growth was more adversely influenced by salt than root growth. However, application of Asn or G resulted in a decrease of the root:shoot ratio. There was a marked reduction in leaf RWC in the maize plants under saline stress compared to that under the control treatment (Tab. 1). However, foliar application of Asn or G caused a significant improvement in RWC in the salt-stressed maize plants and there was more improvementwith glycerol.

Chlorophyll (Chl $a$ and $b$ ) contents decreased significantly in plants grown under $\mathrm{NaCl}$ stress. However, exogenously applied Asn or G increased chlorophyll contents in the salt-stressed plants compared to those in the salt-stressed plants not supplied with Asn or G (Tab. 2). Glycerol was again more effective than asparagine in increasing chlorophyll con- 
Tab. 1. Shoot, root and total plant dry weights, root: shoot ratio and relative water content (RWC) of salt-stressed and non-stressed maize plants, to which asparagine or glycerol were foliar applied (values followed by different letters, in the same column, are significantly different at $\mathrm{p}$ $\leq 0.05$ ). Control treatment (nutrient solution alone); Salt, $100 \mathrm{mM} \mathrm{NaCl} ; \mathrm{A}_{1}$ and $\mathrm{A}_{2}: 5$ and 10 $\mathrm{mM}$ asparagine, respectively; $\mathrm{G}_{1}$ and $\mathrm{G}_{2}: 20$ and $40 \mathrm{mM}$ glycerol, respectively.

\begin{tabular}{lccccc}
\hline Treatments & $\begin{array}{c}\text { Shoot dry wt. } \\
\text { (g per plant) }\end{array}$ & $\begin{array}{c}\text { Root dry wt. } \\
\text { (g per plant) }\end{array}$ & $\begin{array}{c}\text { Root:shoot } \\
\text { ratio }\end{array}$ & $\begin{array}{c}\text { Total plant } \\
\text { dry wt. } \\
\text { (g per plant) }\end{array}$ & $\begin{array}{c}\text { RWC } \\
(\%)\end{array}$ \\
\hline Control & $9.72 \mathrm{a}$ & $1.23 \mathrm{a}$ & $0.127 \mathrm{~d}$ & $10.95 \mathrm{a}$ & $88 \mathrm{a}$ \\
Salt & $5.36 \mathrm{~d}$ & $1.09 \mathrm{c}$ & $0.203 \mathrm{a}$ & $6.45 \mathrm{~d}$ & $65 \mathrm{~d}$ \\
Salt $+\mathrm{A}_{1}$ & $7.24 \mathrm{~b}$ & $1.15 \mathrm{bc}$ & $0.159 \mathrm{~b}$ & $8.39 \mathrm{~b}$ & $72 \mathrm{c}$ \\
Salt $+\mathrm{A}_{2}$ & $6.89 \mathrm{c}$ & $1.12 \mathrm{c}$ & $0.163 \mathrm{~b}$ & $8.01 \mathrm{c}$ & $74 \mathrm{c}$ \\
Salt $+\mathrm{G}_{1}$ & $7.32 \mathrm{~b}$ & $1.15 \mathrm{bc}$ & $0.157 \mathrm{~b}$ & $8.47 \mathrm{~b}$ & $79 \mathrm{~b}$ \\
Salt $+\mathrm{G}_{2}$ & $7.26 \mathrm{~b}$ & $1.16 \mathrm{~b}$ & $0.160 \mathrm{~b}$ & $8.42 \mathrm{~b}$ & $82 \mathrm{~b}$ \\
\hline
\end{tabular}

tents of the salt-stressed maize plants. Electrolyte leakage (EL) is considered to be a promising indicator of stress-induced membrane damage. Electrolyte leakage was markedly greater in the salt-stressed plants than that in the control plants (Tab. 2). However, Asn or G foliar-applied to the salinized plants considerably reduced EL in the leaves compared with the salinity-stressed plants that received neither Asn nor G (Tab. 2). Glycerol was more effective than asparagine in reducing EL in the salt-stressed maize plants.

Tab. 2. Chlorophyll $a$ and chlorophyll $b$ (mg per kg of fresh leaf tissue), electrolyte leakage (\%) and proline content ( $\mu \mathrm{mol}$ per $\mathrm{g}$ fresh weight) of salt-stressed and non-stressed maize plants, to which asparagine or glycerol were foliar applied (values followed by different letters, in the same column, are significantly different at $\mathrm{p} \leq 0.05)$. Control treatment: see table 1 .

\begin{tabular}{lrccc}
\hline Treatments & Chl $a$ & Chl $b$ & Electrolyte leakage & Proline \\
\hline Control & $1289 \mathrm{a}$ & $912 \mathrm{a}$ & $12.3 \mathrm{~d}$ & $1.12 \mathrm{~d}$ \\
Salt & $905 \mathrm{~d}$ & $596 \mathrm{~d}$ & $38.2 \mathrm{a}$ & $2.32 \mathrm{a}$ \\
Salt $+\mathrm{A}_{1}$ & $1056 \mathrm{c}$ & $705 \mathrm{~b}$ & $26.5 \mathrm{~b}$ & $1.32 \mathrm{c}$ \\
Salt $+\mathrm{A}_{2}$ & $1078 \mathrm{c}$ & $712 \mathrm{~b}$ & $25.8 \mathrm{~b}$ & $1.56 \mathrm{~b}$ \\
Salt $+\mathrm{G}_{1}$ & $1109 \mathrm{~b}$ & $778 \mathrm{c}$ & $23.6 \mathrm{c}$ & $1.08 \mathrm{~d}$ \\
Salt $+\mathrm{G}_{2}$ & $1117 \mathrm{~b}$ & $784 \mathrm{c}$ & $22.3 \mathrm{c}$ & $1.01 \mathrm{~d}$ \\
\hline
\end{tabular}

Free proline levels were higher in the maize plants grown under saline stress than in those in the control plants. However, Asn or G foliar-applied to the salinized plants decreased proline levels compared to the salt-stressed-maize plants receiving no treatment of Asn or G (Tab. 2). The effect of foliar application of $G$ in reducing the proline content was more striking than that of Asn.

Salinity stress up-regulated the activities of SOD, CAT and PPO, but it did not alter that of POD. Exogenously applied Asn or G reduced the activities of SOD, POD and PPO in the 
stressed plants compared to those of the salt treated plants not supplied with Asn or G (Tab. 3 ). Although POD activity was not altered due to salt stress, it was reduced considerably due to exogenous application of asparagine or glycerol and there was greater reduction with glycerol application. Glycerol application was again more effective than that of asparagine in reducing the activities of all enzymes.

Tab. 3. Activities of superoxide dismutase (SOD: Unit per mg of protein), polyphenol oxidase (PPO: 100 units per mg of protein), catalase (CAT: 100 units per mg of protein) and peroxidase (POD: $\Delta \mathrm{A}_{470}$ per minute, per mg of protein) in salt-stressed and non-stressed maize plants to which asparagine or glycerol were foliar applied (values followed by different letters, in the same column, are significantly different at $\mathrm{p} \leq 0.05)$. Control treatment: see table 1 .

\begin{tabular}{lllll}
\hline Treatments & SOD & PPO & POD & CAT \\
\hline Control & $29.0 \mathrm{c}$ & $0.35 \mathrm{~d}$ & $0.41 \mathrm{a}$ & $1.02 \mathrm{~d}$ \\
Salt & $41.0 \mathrm{a}$ & $0.53 \mathrm{a}$ & $0.39 \mathrm{a}$ & $1.33 \mathrm{~b}$ \\
Salt $+\mathrm{A}_{1}$ & $33.0 \mathrm{~b}$ & $0.44 \mathrm{~b}$ & $0.21 \mathrm{c}$ & $1.20 \mathrm{c}$ \\
Salt $+\mathrm{A}_{2}$ & $32.0 \mathrm{~b}$ & $0.41 \mathrm{bc}$ & $0.38 \mathrm{a}$ & $1.40 \mathrm{a}$ \\
Salt $+\mathrm{G}_{1}$ & $28.0 \mathrm{~cd}$ & $0.38 \mathrm{~cd}$ & $0.31 \mathrm{~b}$ & $1.17 \mathrm{c}$ \\
Salt $+\mathrm{G}_{2}$ & $26.0 \mathrm{~d}$ & $0.38 \mathrm{~cd}$ & $0.20 \mathrm{c}$ & $0.97 \mathrm{~d}$ \\
\hline
\end{tabular}

Saline growth medium caused a marked increase in leaf $\mathrm{Na}^{+}$but a decrease in those of leaf $\mathrm{K}^{+}, \mathrm{Ca}^{2+}$ and $\mathrm{P}$ in maize plants. The maize plants grown under saline regime accumulated considerably lower $\mathrm{Na}^{+}$and higher $\mathrm{K}^{+}, \mathrm{Ca}^{2+}$ and $\mathrm{P}$ upon foliar applications of Asn or $\mathrm{G}$ than the salt-stressed plants that did not receive Asn or G (Tab. 4). Sodium:potassium $(\mathrm{Na}: \mathrm{K})$ ratio was found to be elevated significantly in the leaves of maize plants exposed to $\mathrm{NaCl}$ stress, but exogenously applied Asn or $\mathrm{G}$ to salinized plants significantly decreased the Na:K ratio. Asparagine was found to be more effective than glycerol in improving the contents of $\mathrm{Ca}^{2+}$ and $\mathrm{K}^{+}$in the leaves of salt-stressed maize plants, but it was less effective in reducing leaf $\mathrm{Na}^{+}$.

Tab. 4. $\mathrm{Na}^{+}, \mathrm{Ca}^{2+}, \mathrm{K}^{+}$and $\mathrm{P}$ content (mmol per $\mathrm{kg}$ of dry matter) in leaves and roots of salt-stressed and non-stressed maize plants, to which asparagine or glycerol were foliar applied. Values followed by different letters, in the same column, are significantly different at $p \leq 0.05$. Control treatment: see table 1 .

\begin{tabular}{|c|c|c|c|c|c|c|c|c|c|}
\hline \multirow{2}{*}{ Treatments } & \multicolumn{5}{|c|}{ Leaf } & \multicolumn{4}{|c|}{ Root } \\
\hline & $\mathrm{Na}^{+}$ & $\mathrm{Ca}^{2+}$ & $\mathrm{K}^{+}$ & $\mathrm{P}$ & $\mathrm{Na}^{+}: \mathrm{K}^{+}$ & $\mathrm{Na}^{+}$ & $\mathrm{Ca}^{2+}$ & $\mathrm{K}^{+}$ & $\mathrm{P}$ \\
\hline & $29 \mathrm{c}$ & $168 \mathrm{~b}$ & $956 \mathrm{c}$ & $122 \mathrm{a}$ & $0.030 \mathrm{e}$ & $99 \mathrm{c}$ & $165 \mathrm{a}$ & $122 \mathrm{a}$ & $21 \mathrm{ab}$ \\
\hline Salt & $328 \mathrm{a}$ & $112 \mathrm{e}$ & $673 d$ & $86 \mathrm{~d}$ & $0.487 \mathrm{a}$ & $278 \mathrm{a}$ & $78 \mathrm{~d}$ & $72 \mathrm{~d}$ & $14 \mathrm{c}$ \\
\hline Salt $+A_{1}$ & $320 \mathrm{a}$ & $178 \mathrm{a}$ & $887 \mathrm{~b}$ & $105 \mathrm{~b}$ & $0.360 \mathrm{~b}$ & $179 \mathrm{~b}$ & $103 \mathrm{c}$ & $106 \mathrm{~b}$ & $21 \mathrm{ab}$ \\
\hline Salt $+\mathrm{A}_{2}$ & $300 \mathrm{~b}$ & $182 \mathrm{a}$ & $898 \mathrm{~b}$ & $99 \mathrm{c}$ & $0.334 \mathrm{c}$ & $187 \mathrm{~b}$ & $105 \mathrm{c}$ & $107 \mathrm{~b}$ & $23 \mathrm{a}$ \\
\hline Salt $+\mathrm{G}_{1}$ & $265 c$ & $148 \mathrm{~d}$ & $765 d$ & $109 \mathrm{~b}$ & $0.346 \mathrm{bc}$ & $189 \mathrm{~b}$ & $117 \mathrm{~b}$ & $98 \mathrm{c}$ & $18 \mathrm{~b}$ \\
\hline Salt $+\mathrm{G}_{2}$ & $243 \mathrm{~d}$ & $159 \mathrm{c}$ & $812 \mathrm{e}$ & $111 \mathrm{~b}$ & $0.299 \mathrm{~d}$ & $176 \mathrm{~b}$ & $114 \mathrm{~b}$ & $103 \mathrm{~b}$ & $23 \mathrm{a}$ \\
\hline
\end{tabular}




\section{Discussion}

From the data for different growth attributes such as shoot and root dry weights and total plant dry biomass, it is amply clear that foliar-applied asparagine or glycerol improved the growth of salt-stressed maize plants as compared to those not supplied with asparagine or glycerol. However, growth improvement was more marked with glycerol than with asparagine. The relatively greater effectiveness of glycerol in promoting the growth of salt-stressed maize plants can be related to the data for RWC, plant pigments (Chl. $a$ and $b$ ) and electrolyte leakage. It is pertinent to note, however, that both asparagine and glycerol increased RWC and chlorophyll $a$ and $b$ contents, and reduced electrolyte leakage in the salt-treated maize plants compared with those not treated with asparagine or glycerol. Thus, the greater improvement in the growth of maize plants with glycerol application could have been due to a substantial glycerol-induced increase in RWC and chlorophyll $a$ and $b$ contents, and a decrease in electrolyte leakage. Glycerol is a common cellular metabolite that acts effectively as both an osmoregulator and an osmoprotectant (SHEN et al. 1999, ASHRAF and HARRIS 2004, COURCHESNE et al. 2011). It is also one of the vital intermediates involved in energy metabolism in both prokaryotes and eukaryotes (FERREIRA et al. 2005). In a recent study, exogenous application of glycerol as a pre-sowing seed treatment to salt-stressed Ricinus communis plants resulted in a marked improvement in growth (ALI et al. 2008).

Electrolyte leakage from cellular membranes is one of the prominent salinity-induced effects on most plants. This membrane characteristic is contemplated as one of the viable indicators of salt tolerance (SAIRAM et al. 2002, AsHrAF and Ali 2008, MANSOUR 2012). The considerable effect of glycerol on checking electrolyte leakage in the salt-stressed maize plants could be because exogenously applied glycerol might increase intra-cellular glycerol concentration, which in turn, alters membrane permeability, as earlier reported by BROWN (1990) and ALBERTYN et al. (1994). It is also possible that glycerol stabilized cell membrane proteins including transport proteins to check electrolyte leakage (SCHEIN 1990).

The growth of salt-stressed maize plants was also improved with asparagine application, though less than with glycerol. Such improvement in growth due to exogenous application of asparagine was earlier observed in rice (LIN and KAO 1995). Like other important amino acids and amides, asparagine serves as a vital nitrogen and carbon reservoir during osmotic stress (MARTinelli et al. 2007, SuliEMAn et al. 2010). Despite the involvement of asparagine in the storage of reduced $\mathrm{N}$ in salt-stressed plants (STEWART and LARHER 1980, RABE 1990), it plays a central role in osmoregulation of plants exposed to osmotic stress (COLMER et al. 1995, MAAroufi-DGuimi et al. 2011).

Accumulation of compatible osmolytes is one of the distinctive responses of plants subjected to salt stress. Among different compatible osmolytes known in plants, proline has been widely studied because it plays a multitude of functions in the metabolism of plants subjected to salt stress, in addition to its significant role in osmoregulation as well as osmoprotection (ASHRAF and FoOLAD 2007). The data for proline content shows that proline content decreased markedly in salt-stressed maize plants supplied with asparagine or glycerol. However, more reduction took place in proline due to glycerol application. A strong body of evidence shows that both asparagine (ASHRAF and HARRIS 2004, LEA et al. 2007) and glycerol (FERREIRA et al., 2005, MARTINELLI et al. 2007) are also potential osmolytes and analogous to proline in regulating many physio-biochemical processes. It is highly likely that the reduction in proline content in salt-stressed plants may have been due to an antagonistic effect of asparagine and glycerol with proline. 
Although salt stress enhanced the activities of some key antioxidant enzymes, SOD, PPO and CAT, the exogenously applied asparagine and glycerol considerably reduced the activities of these enzymes while glycerol was more effective in reducing the antioxidant enzyme activities. It is now evident that glycerol could act as a scavenger of reactive oxygen species (ROS) possibly generated by different stresses including salt stress (SMIRNOFF and Cumbes 1989, SHeveleva et al. 1997, SHEN et al. 1999). Thus, in cases in which other alternative ROS scavengers are available to plants, a reduction in the levels of antioxidant enzymes determined in the present study can be expected. Although asparagine also caused reduction in the activities of antioxidant enzymes in salt-stressed maize plants, its role as an antioxidant has not been established (LIU et al. 2004).

Exogenous application of asparagine and glycerol was also found to be effective in regulating the levels of different elements such as $\mathrm{Na}^{+}, \mathrm{K}^{+}, \mathrm{Ca}^{2+}$ and $\mathrm{P}$ in the leaves and roots of salt-stressed maize plants. Exogenously applied glycerol reduced leaf $\mathrm{Na}^{+}$more effectively than asparagine, although both osmolytes remained almost equally effective in reducing root $\mathrm{Na}^{+}$. This could also be one of the reasons for the greater effectiveness of glycerol than asparagine in improving growth of salt-stressed maize plants. However, in contrast, asparagine was more effective in improving leaf $\mathrm{Ca}^{2+}$ and $\mathrm{K}^{+}$as well as root $\mathrm{K}^{+}$in salt-stressed maize plants. The differential effectiveness of glycerol and asparagine in regulating the levels of important inorganic nutrients may have been one of the factors in the differential improvement of growth in salt-stressed maize plants.

Overall, foliar application of asparagine or glycerol caused a substantial improvement in growth of maize plants of genotype DK 647 F1 under salt stress. This asparagine- or glycerol-induced growth improvement was found to be associated with improved relative water content and photosynthetic pigments and decreased electrolyte leakage from cellular membranes in this maize genotype. Both glycerol and asparagine significantly reduced leaf proline content and the activities of SOD, PPO and CAT and differentially regulated the levels of different inorganic nutrients in salt-stressed plants of the genotype. Glycerol was found to be more effective than asparagine in regulating growth and physiological processes in salt-stressed plants of the genotype because it has a dual function i.e. as an osmolyte and as a scavenger of reactive oxygen species, whereas the function of asparagine as an antioxidant has not yet been established. We have used only one genotype to examine the effects of glycerol and asparagine, and the results presented here cannot be generalized unless such effects are observed in a number of maize genotypes.

\section{Acknowledgement}

The authors wish to thank the University of Harran and University of Agriculture, Faisalabad, (Pakistan) for providing the facilities for this work.

\section{References}

Agarwal, S., Pandey, V., 2004: Antioxidant enzyme responses to $\mathrm{NaCl}$ stress in Cassia angustifolia. Biologia Plantarum 48, 555-560.

Albert, R., PopP, M., 1977: Chemical composition of halophytes from the Neusiedler Lake region in Austria. Oecologia Plantarum 27, 157-170. 
Albertyn, J., Hohmann, S., Thevelein, J. M., Prior, B. A., 1994: GPD1, which encodes glycerol-3 phosphate dehydrogenase, is essential for growth under osmotic stress in Saccharomyces cerevisiae, and its expression is regulated by the high-osmolarity glycerol response pathway. Molecular cell biology 14, 4135-4144.

Ali, R. M., ElfeKY, S. S., ABBAS, H., 2008: Response of salt-stressed Ricinus communis L: to exogenous application of glycerol and/or aspartic acid. Journal of Biological Sciences $8,171-175$.

ASHRAF, M., 2009: Biotechnological approach of improving plant salt tolerance using antioxidants as markers. Biotechnology Advances 27, 84-93.

AsHRAF, M., ALI, Q., 2008: Relative membrane permeability and activities of some antioxidant enzymes as the key determinants of salt tolerance in canola (Brassica napus L.). Environmental and Experimental Botany 63, 266-273.

Ashraf, M., HARRIS, P. J. C., 2004: Potential biochemical indicators of salinity tolerance in plants. Plant Science 166, 3-16.

Ashraf, M., Athar, H. R., HARRIS, P. J. C., KwON, T. R., 2008: Some prospective strategies for improving crop salt tolerance. Advances in Agronomy 97, 45-110.

AshraF, M., FoOLAD, M. R., 2007: Roles of glycine betaine and proline in improving plant abiotic stress resistance. Environmental and Experimental Botany 59, 206-216.

BARRs, H. D., WeATHERLEY, P. E., 1962: A re-examination of the relative turgidity technique for estimating water deficits in leaves. Australian Journal of Biology Sciences 15, 413-428.

Bates, L. S., Waldren, R. P., Teare, I. D., 1973: Rapid determination of free proline for water stress studies. Plant and Soil 39, 205-207.

Beauchamp, C., Fridovich, I. 1971: Superoxide dismutase: Improved assays and an assay applicable to acryl- amide gels. Analytical Biochemistry 44, 276-287.

BRADFORD, M. M., 1976: A rapid and sensitive method for the quantitation of microgram quantities of protein utilizing the principle of protein-dye binding. Analytical Biochemistry $72,248-254$.

Brouluisse, R., James, F., Pradet, A., Raymond, P., 1992: Asparagine metabolism and nitrogen distribution during protein degradation in sugar-starved maize root tips. Planta $188,384-395$.

Brown, A. D., 1990: Microbial water stress physiology, principles and perspectives. John Wiley \& Sons, New York.

Chaffei, C., Pageau, K., Suzuki, A., Gouia, H., Ghorbel, M. H., Masclaux-Daubresse, C., 2004: Cadmium toxicity induced changes in nitrogen management in Lycopersicon esculentum leading to a metabolic safeguard through an amino acid storage strategy. Plant Physiology 45, 1681-1693.

Chance, M., Maehly, A. C., 1955: Assay of catalases and peroxidases. Methods of Enzymology 2, 764-817.

Chapman, H. D., Pratt, P. F., 1982: Methods of plant analysis. I. Methods of analysis for soils, plants and water. Chapman Publishers, Riverside, CA

Cheeseman, J. M., 1988: Mechanism of salt tolerance in plants. Plant Physiology 87, 547-550.

Colmer, T. D., EPSTEIN, E., DvorAK, J., 1995: Differential solute regulation in leaf blades of various ages in salt sensitive wheat and a salt-tolerant wheat $\mathrm{x}$ Lophopyrum elongatum (Host.) A. Love amphiploid. Plant Physiology 108, 1715-1724. 
Courchesne, W. E., Vlasek, C., Klukovich, R., Coffee, S., 2011: Ethanol induces calcium influx via the Cch1-Mid1 transporter in Saccharomyces cerevisiae. Archives of Microbiology 193, 323-334.

Cushman, J. C., Derocher, E. J., Bohnert, H. J., 1990: Gene expression during adaptation to salt stress. In: KATERMAN, F. J., (ed.) Environmental injury to plants. 173-203. Academic press, New York.

DAVIES, K. J. A., 1987: Protein damage and degradation by oxygen radicals, 1. General aspects. Journal of Biological Chemistry 262, 9895-9901.

DEMIR, Y., KoCALISKAN, I., 2001: Effects of $\mathrm{NaCl}$ and proline on polyphenol oxidase activity in bean seedlings. Biologia Plantarum 44, 607-609.

Dionisio-Sese, M. L., Tobita, S., 1998: Antioxidant responses of rice seedlings to salinity stress. Plant Science 135, 1-9.

Ferreira, C., Voorst, F. V., Neves, A. M. L., Oliveira, R., Kielland-Brandt, M. C., Lucas, C., BRANDT, A., 2005. A member of the sugar transporter family, Stllp is the glycerol/ $\mathrm{H}^{+}$ symporter in Saccharomyses cerevisiae. Molecular Biology of the Cell 16, 2068-2076.

FougÈre, F., LE RUdULIER, D., STREETER, J. G., 1991: Effects of salt stress on amino acid, organic acid, and carbohydrate composition of roots, bacteroids, and cytosol of alfalfa (Medicago sativa L.). Plant Physiology 96, 1228-1236.

Greenway, H., Munns, R., 1980: Mechanisms of salt tolerance in nonhalophytes. Annual Review of Plant Physiology 312, 149-190.

Herrera-Rodriguez, M. B., Perez-Vicente, R., Maldonado, J. M., 2007: Expression of asparagine synthetase genes in sunflower (Helianthus annuus) under various environmental stresses. Plant Physiology and Biochemistry 45, 33-38.

JAGER, H. J., MEYER, H. R., 1977: Effect of water stress on growth and proline metabolism of Phaseolus vulgaris L. Oecologia 30, 83-96.

Kraus, T. E., Austin-Fletcher, R. A., 1994: Paclobutrazol protects wheat seedlings from heat and paraquat injury: is detoxification of active oxygen involved? Plant and Cell Physiology 35, 45-52.

LÄUChli, A., GRATTAN, S. R., 2007: Plant growth and development under salinity stress. In: Jenks, M. A., Hasegawa, P. M., Jain, S. M. (eds.), Advances in molecular breeding toward drought and salt tolerant crops, 1-32. Springer.

Lea, P. J., Sodek, L., Parry, M. A. J., Shewry, P. R., Halford, N. G., 2007: Asparagine in plants. Annual in Applied Biology 150, 1-126.

LiN, C. C., KAO, C. H., 1995: NaCl stress in rice seedlings: effects of L-proline, glycinebetaine, L- and D-asparagine on seedling growth. Biologia Plantarum 37, 305-308.

LiU, D. Z., LiN, Y. S., Hou, W. C., 2004: Monohydroxamates of aspartic acid and glutamic acid exhibit antioxidant and angiotensin converting enzyme inhibitory activities. Journal of Agricultural and Food Chemistry 52, 2386-2390.

Mansour, M. M. F., 2013: Plasma membrane permeability as an indicator of salt tolerance in plants. Biologia Plantarum. In press.

Martinelli, T., Anne, W., Adriana, B., Concetta, V., Akira, S., Celine, M., 2007: Amino acid pattern and glutamate metabolism during dehydration stress in the resurrection' plant Sporobolus stapfianus: a comparison between desiccation-sensitive and desiccation tolerant leaves. Journal of Experimental Botany 58, 3037-3046. 
Maaroufi-Dguimi, H., Debouba, M., Gaufichon, L., Clément, G., Gouia, H., Hajuaji, A., SuZUKI, A., 2011: An Arabidopsis mutant disrupted in ASN2 encoding asparagine synthetase 2 exhibits low salt stress tolerance. Plant Physiology and Biochemistry 49, $623-628$.

RABE, E., 1990: Stress physiology: the functional significance of the accumulation of nitrogen-containing compounds. Journal of Horticultural Science 65, 231-243.

SAIRAM, R. K., RAo K. V., SrivastaVA, G. C., 2002: Differential response of wheat genotypes to long-term salinity stress in relation to oxidative stress, antioxidant activity and osmolyte concentration. Plant Science 163, 1037-1046.

SCHEIN, C. H., 1990: Solubility as a function of protein structure and solvent components. Biotechnology 8, 308-317.

Shen, B., Hohmann, S., Jensen, J. G., Bohnert, H. J., 1999: Roles of sugar alcohols in osmotic stress adaptation. Replacement of glycerol by mannitol and sorbitol in yeast. Plant Physiology 121, 45-52.

Sheveleva, E., Chmara, W., Bohnert, H. J., Jensen, R. G., 1997: Increased salt and drought tolerance by D-ononitol production in transgenic Nicotiana tabacum L. Plant Physiology 115, 1211-1219.

Sieciechowicz, K. A., Joy, K. W., Ireland, R. J., 1988: The metabolism of asparagine in plants. Phytochemistry 27, 663-671.

SMIRnOFF, N., CumBes, Q. J., 1989: Hydroxyl radical scavenging of compatible solutes. Phytochemistry 28, 1057-1060.

Stewart, G. R., LARHER, F., 1980: Accumulation of amino acids and related compounds in relation to environmental stress. In: MifLIN, B. J. (ed.), The biochemistry of plants, 609-635. Academic Press, New York.

Stoop, J. M. H., Williamson, J. D., Pharr, D. M., 1996: Mannitol metabolism in plants: A method for coping with stress. Trends in Plant Science 1, 139-144.

Storey, R., Wyn Jones, R. G., 1977: Quaternary ammonium compounds in plants in relation to salt stress. Phytochemistry 16, 447-453.

Strain, H. H., Svec, W. A., 1966: Extraction, separation, estimation and isolation of chlorophylls. In: Vernon, L. P., SEely, S. R. (eds), The chlorophylls, 21-66. Academic Press, New York.

Sulieman, S., Fischinger, S. A., Gresshoff, P. M., 2010: Asparagine as a major factor in the $\mathrm{N}$-feedback regulation of $\mathrm{N}_{2}$ fixation in Medicago truncatula. Physiologia Plantarum 140, 21-31.

Thomas, J. C., DE ARMond, R. L., BohnerT, H. J., 1992: Influence of NaCl on growth, proline and phosphoenolpyruvate carboxylase levels in Mesembrythemum crystallinum suspension cultures. Plant Physiology 98, 926-931.

Williams, D. C., Lim, M. H., Chen, A. O., Pangborn, R. M., Whitaker, J. R., 1986: Blanching of vegetables for freezing-which indicator enzyme to choose. Food Technology 40, $130-140$.

Yamaguchi, T., Blumdwald, E., 2005: Developing salt-tolerant crop plants: Challenges and opportunities. Trends in Plant Science 12, 615-620.

Zauberman, Z., Roren, R., Akerman, I., WeKsler, A., Fuch, Y., 1991: Post harvest retention of the red color of litchi fruit pericarp. Scientia Horticulturae 47, 89-97. 